\title{
Role of Non-Coding Variants in Brugada Syndrome
}

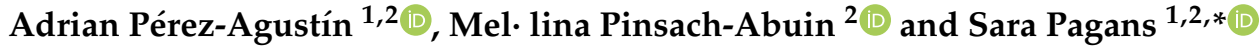 \\ 1 Department of Medical Sciences, School of Medicine, University of Girona, 17003 Girona, Spain; \\ adriaperez@gencardio.com \\ 2 Biomedical Research Institute of Girona, 17190 Salt, Spain; mpinsach@gencardio.com \\ * Correspondence: sara.pagans@udg.edu
}

Received: 14 October 2020; Accepted: 10 November 2020; Published: 13 November 2020

\begin{abstract}
Brugada syndrome (BrS) is an inherited electrical heart disease associated with a high risk of sudden cardiac death (SCD). The genetic characterization of BrS has always been challenging. Although several cardiac ion channel genes have been associated with BrS, SCN5A is the only gene that presents definitive evidence for causality to be used for clinical diagnosis of BrS. However, more than $65 \%$ of diagnosed cases cannot be explained by variants in SCN5A or other genes. Therefore, in an important number of $\mathrm{BrS}$ cases, the underlying mechanisms are still elusive. Common variants, mostly located in non-coding regions, have emerged as potential modulators of the disease by affecting different regulatory mechanisms, including transcription factors (TFs), three-dimensional organization of the genome, or non-coding RNAs (ncRNAs). These common variants have been hypothesized to modulate the interindividual susceptibility of the disease, which could explain incomplete penetrance of BrS observed within families. Altogether, the study of both common and rare variants in parallel is becoming increasingly important to better understand the genetic basis underlying $\mathrm{BrS}$. In this review, we aim to describe the challenges of studying non-coding variants associated with disease, re-examine the studies that have linked non-coding variants with $\mathrm{BrS}$, and provide further evidence for the relevance of regulatory elements in understanding this cardiac disorder.
\end{abstract}

Keywords: Brugada syndrome; arrhythmia; sudden cardiac death; non-coding variants; gene regulation; cis-regulatory elements; non-coding RNAs; SCN5A; SCN10A

\section{Introduction}

Brugada syndrome (BrS) was first described in 1992 as a rare inherited cardiac disease. It is characterized by a distinctive electrocardiographic pattern with a coved-type ST-segment elevation in the right precordial leads [1]. This disorder is associated with a high risk of sudden cardiac death (SCD) among the population, and has been found to be responsible for $15-20 \%$ of supraventricular arrhythmias and atrial fibrillation (AF) cases in structural normal hearts [2].

To date, the best-known cause of $\mathrm{BrS}$ is the presence of variants at the coding regions of the SCN5A gene, accounting for approximately $20-25 \%$ of BrS cases [3]. SCN5A encodes the $\alpha$-subunit of the voltage-gated cardiac sodium channel $\left(\mathrm{Na}_{\mathrm{V}} 1.5\right)$, which is responsible for the rapid influx of sodium ions that initiates the propagation of the action potential in cardiac muscle cells [4]. These variants in SCN5A include single nucleotide variants (SNVs), as well as small insertions and deletions (Indels), and have been associated with $\mathrm{Na}_{\mathrm{V}} 1.5$ loss of function, either affecting its channel activity or reducing the number of channels at the plasma membrane [3]. Other genes, such as $S C N 1 B, S C N 2 B, S C N 3 B$, $C A C N A 1 C, C A C N B 2$, or $C A C N A 2 D 1$, have also been associated with the disease with a lower incidence, representing 5-10\% of BrS cases [5-7]. However, their relevance is still questioned because of their lack of definitive evidence for causality [8]. Therefore, in more than $65 \%$ of $\mathrm{BrS}$ diagnosed patients, the etiology of the disease is still unknown. 
BrS has traditionally been considered a monogenic disease with an autosomal dominant mode of transmission [9]. However, in recent years, several observations have provided evidence to suggest that $\mathrm{BrS}$ has a more complex inheritance and a heterogeneous genetic basis [10-12]. Furthermore, it has been observed that BrS-associated variants show low penetrance $[10,13]$. For instance, studies conducted in families carrying SCN5A pathogenic variants have estimated a BrS penetrance of $12.5-50 \%$, with an average of $16 \%$ [9]. Additionally, it is well-established that age, gender, environmental factors, and comorbidities contribute to the BrS phenotype [14]. As new genetic studies appear, it is becoming more evident that both coding and non-coding regions play a fundamental role in the pathophysiology of inherited human diseases, including BrS [10]. The challenges surrounding the complex genetics of $\mathrm{BrS}$, and the evidence suggesting that this disorder may not be caused by single genetic variants, have also been recently discussed by Monasky and colleagues [15].

Historically, most genetic studies have been focused on studying variants in coding regions. However, during the last ten years, genome-wide association studies (GWAS) have uncovered that most disease-associated variants lie within non-coding regions, especially at cis-regulatory regions [16]. This has led to an increasing interest in examining the role of regulatory variants in inherited diseases. In this regard, a recent analysis of 150 million SNVs in 10,000 human genomes revealed that genetic variation is unevenly distributed across the human genome, and that promoters, transcription factor binding sites (TFBSs), open-chromatin regions, and CCCTC-binding factor (CTCF) sites, in this order, accumulate the largest number of SNVs in regulatory elements across the human genome [17]. Similarly, it has been proposed that the presence of variants at cis-regulatory elements (CREs) and non-coding RNAs (ncRNAs) involved in modulating the expression levels of cardiac ion channels could be a mechanism underlying the BrS phenotype [12,18].

From GWAS and other genetic studies, we have learnt that there is often a correlation between the severity and frequency of variants, where variants with a major impact are rare (minor allele frequency $(\mathrm{MAF})<1 \%$ ) and those with limited impact are common (MAF $\geq 5 \%$ ) [19]. As a result, common variants could be exacerbating or attenuating the disease manifestation alongside a primary genetic defect, which is usually described in a coding region, but these variants can also be responsible for the disease phenotype in the absence of coding variants [20]. A further source of complexity is that a common variant in one particular population can be rare in another one [21]. Therefore, it has been suggested that, in some cases, the disease phenotype might be modulated through an abnormal combination of common variants [22,23]. This has led to an increasing interest in common non-coding variants as potential modulators of the BrS phenotype by fine-tuning the effect of coding variants. Indeed, similar synergistic effects with rare variants have already been described for common variants in the SCN5A coding region [24].

\section{The Challenges Surrounding Non-Coding Variants}

\subsection{Functional Effects of Non-Coding Variants}

The functional effect of variants in coding regions is easy to predict, since the genetic code is already known and there is an important amount of available exome data, as well as a good knowledge of Mendelian disorders [25]. However, the effect of variants in non-coding regions is difficult to assess. These non-coding variants can be found within CREs, such as enhancers, promoters, and insulators, as well as regions that encode ncRNAs. Importantly, all these elements precisely coordinate gene expression, both in a spatial and temporal way [26].

Promoters, enhancers, and insulators harbour TFBSs that regulate their activity [27]. An enhancer is a DNA element recognized by specific TFs that increase transcription of its regulated genes. Enhancers can be located either upstream or downstream from the transcription start site (TSS), and up to $1 \mathrm{Mb}$ away from their target gene [28]. In contrast, promoters are DNA elements recognized by general TFs and the RNA polymerase, and are located near the TSS [29]. On a more global scale, insulators control the accessibility of regulatory elements between well-defined genomic territories, known as 
topological associating domains (TADs), which are hubs of chromatin interactions that establish the limits of action of regulatory regions in the human genome [30,31].

Cis-regulatory variants could have different outcomes depending on the nucleotide change and the position of the variant. For instance, a cis-regulatory, non-coding variant could disrupt the binding of TFs to CREs, changing the accessibility of DNA to TFs or altering the spatial organization of the genome [32-34] (Figure 1A). A unique regulatory variant could also create a new TFBS, thereby altering the existing regulatory network and generating alternative regulatory pathways [35] (Figure 1B). In addition, non-coding variants affecting the accessibility of DNA have been linked with alterations in the binding of chromatin-binding proteins, which may result in alterations in gene expression [36,37]. Similarly, variants within CTCF-binding sites may affect the spatial organization of the genome, leading to alterations of the transcriptional networks [38,39] (Figure 1C). As an example, variants at CTCF cohesin binding sites have been associated with colorectal cancer and with T-cell acute lymphoblastic leukemia [40,41].

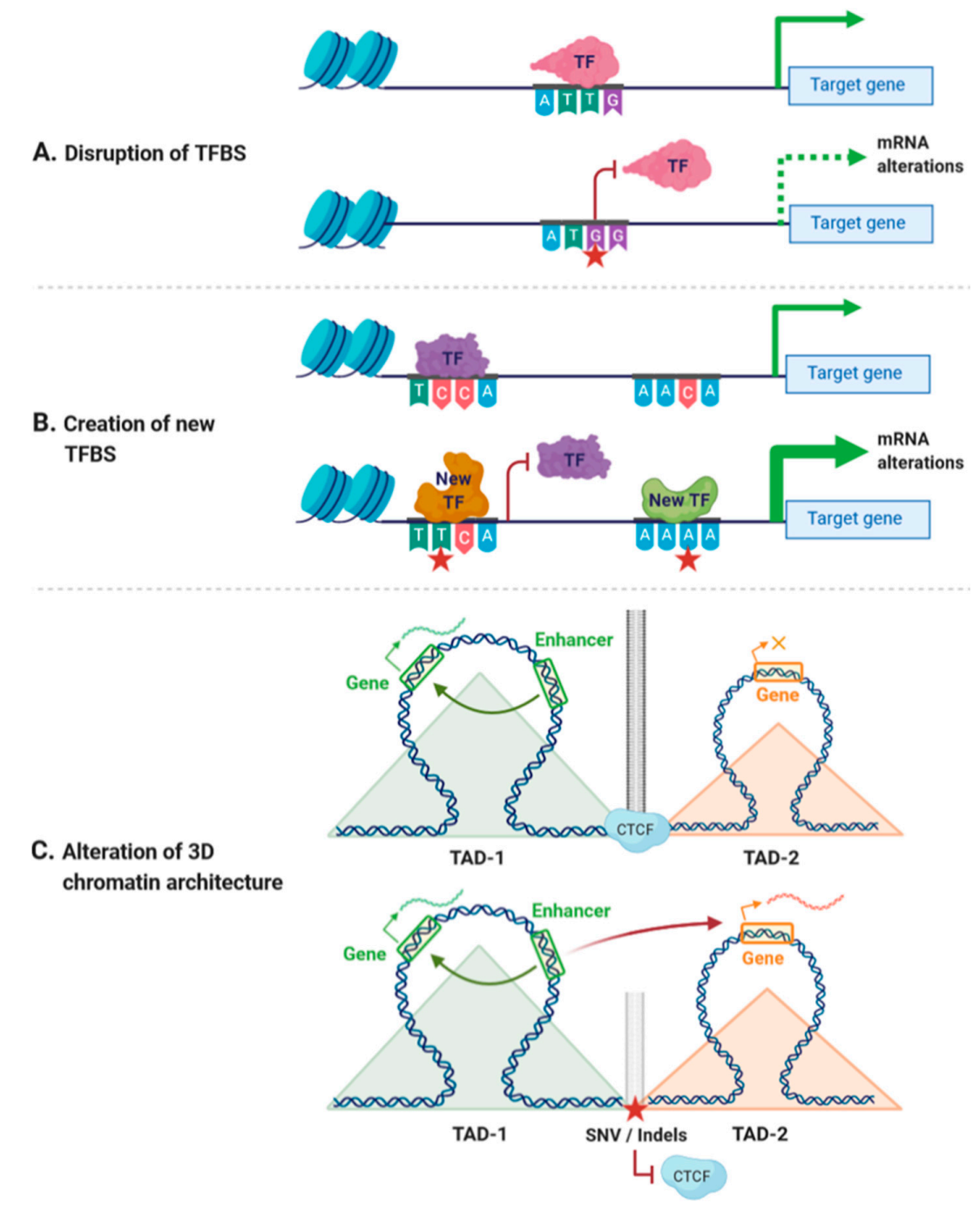

Figure 1. Effects of cis-regulatory variants. (A) Variants within cis-regulatory regions can disrupt transcription factor binding sites (TFBSs), leading to decreased mRNA expression. (B) Variants within cis-regulatory regions can create new TFBSs and generate new regulatory pathways. (C) Variants affecting the binding of CCCTC-binding factor (CTCF) can disrupt insulator activity between two topological associating domains (TADs), generating new enhancer-promoter interactions that may lead to altered expression of genes within these TADs. Red star indicates the position of a new single nucleotide variant (SNV) or an insertion/deletion (Indel). Orange $\times$ indicates inhibition of gene expression. 
Despite the previous examples, in most cases, alterations in TF binding (either due to variants on the TFBS or the DNA-binding domain of the TF) do not have huge effects on transcription levels, and for this reason they are thought to act as genetic modifiers [42]. TFBS contain nucleotides with different relevance for the binding of TFs. The more conserved nucleotides, also referred to as core nucleotides, are essential for TF binding. Therefore, genetic variants affecting core nucleotides will have a higher impact on TF binding. In contrast, the less conserved nucleotides are thought to confer some tolerance to genetic variation, which might explain why many changes in TFBS do not result in measurable alterations in mRNA levels [43]. In addition, low effects of cis-regulatory variants, especially in enhancer elements, could also be explained by the concept of regulatory redundancy [44]. In a recent report, Osterwalder and colleagues observed that deletion of a single enhancer in genes surrounded by multiple enhancers did not result in phenotypic changes, whereas the deletion of more than one resulted in measurable alterations. These findings suggest that enhancers present a robustness to genetic variation when acting together, and that their contribution to gene regulation is more likely redundant rather than additive [45]. In addition, other studies have recently proposed that the regulatory outcome not only depends on the affinity of the TF towards a DNA sequence, but also on a balance between TF affinity and regulatory syntax (order, spacing, and orientation of binding sites), and that an optimal syntax can compensate a weak TFBS, and vice versa [46]. Altogether, the mechanisms of TF binding and promoter/enhancer function reduce the likelihood of large effects produced by a single variant. This would be consistent with multiple studies suggesting that common regulatory variants should be studied in combination and not isolated [15,22].

As mentioned above, non-coding variants can also be found in ncRNAs. ncRNAs are largely classified into microRNAs (miRNAs) and long non-coding RNAs (lncRNAs), although other types of ncRNAs have also been described, including bi-functional coding and non-coding RNAs (cncRNAs) or circular RNAs (circRNAs) [47]. ncRNAs have been shown to have important roles in modulating gene expression at either the mRNA or protein level. They participate in several key functions related to chromatin structure, as well as transcription and post-transcriptional processes [48]. Notably, it is estimated that all known ncRNAs would target more than $60 \%$ of the coding genes [49].

MicroRNAs (miRNAs) are a large class of evolutionarily conserved ncRNAs, 20 to 26 nucleotides in length, that are expressed in a tissue-specific manner. miRNAs post-transcriptionally regulate the flow of genetic information by inhibiting mRNA translation or promoting mRNA degradation [50]. Typically, miRNAs interact with the $3^{\prime}$ untranslated region (UTR) of specific mRNAs, giving rise to the degradation or stabilization of the target sequence [51]. Large molecules of pri-miRNA are cleaved by Drosha into a pre-miRNA, which is further processed in the cytosol by Dicer to obtain the mature miRNA. Mature miRNAs will load into the RNA-induced silencing complex (RISC) to degrade the target mRNA or inhibit its translation [52] (Figure 2). During recent years, it has become evident that miRNAs play central roles in many fundamental biological processes, and that aberrant expression of miRNAs is causally related to a variety of disease states like cancer, diabetes, or cardiovascular diseases [53-55]. miRNAs have been shown to play an essential role in cardiac physiology and pathophysiology [56]. In the cardiac conduction system, specific miRNAs targeting cardiac ion channels have been identified [57], thereby suggesting that variants affecting the function of these miRNAs may have an important impact in modulating the phenotype of inherited cardiac arrhythmias.

lncRNAs are non-protein-coding transcripts longer than 200 nucleotides, involved in a large number of diverse functions due to their ability to fold into different structures [58]. The mechanism of action of lncRNAs is different depending on whether they are in the nucleus or in the cytoplasm (Figure 2). Inside the nucleus, IncRNAs can influence transcription by repressing or activating genes, acting as a scaffold both for TFs, to modulate transcription, and for chromatin remodeling proteins, to modify chromatin accessibility [59]. At a post-transcriptional level, in the cytoplasm, lncRNAs can change the stability of mRNAs, but they can also affect miRNAs by acting as a miRNA sponge (avoiding the repression of the miRNA target) or directly blocking miRNAs. Furthermore, they can bind to ribosomes interfering with the translation of mRNAs [59]. 
During the recent years, an increasing number of lncRNAs have been linked to cardiac disorders. For instance, the so-called Braveheart lncRNA has been associated with cardiac development and disease $[60,61]$, while the lncRNA Fendrr has been shown to be a key factor during cardiac morphogenesis [62,63]. Both Braveheart and Fendrr have been suggested to interact with chromatin regulatory proteins, such as the Polycomb repressive complex 2 (PRC2) [64]. Other studies have reported that the levels of circulating cardiac lncRNAs are altered in patients with cardiomyopathy or heart failure [65-67], and several lncRNAs have been recently linked with different heart diseases. For instance, IncRNAs ANRIL and MIAT are considered risk factors associated with coronary disease and myocardial infarction, respectively $[68,69]$.

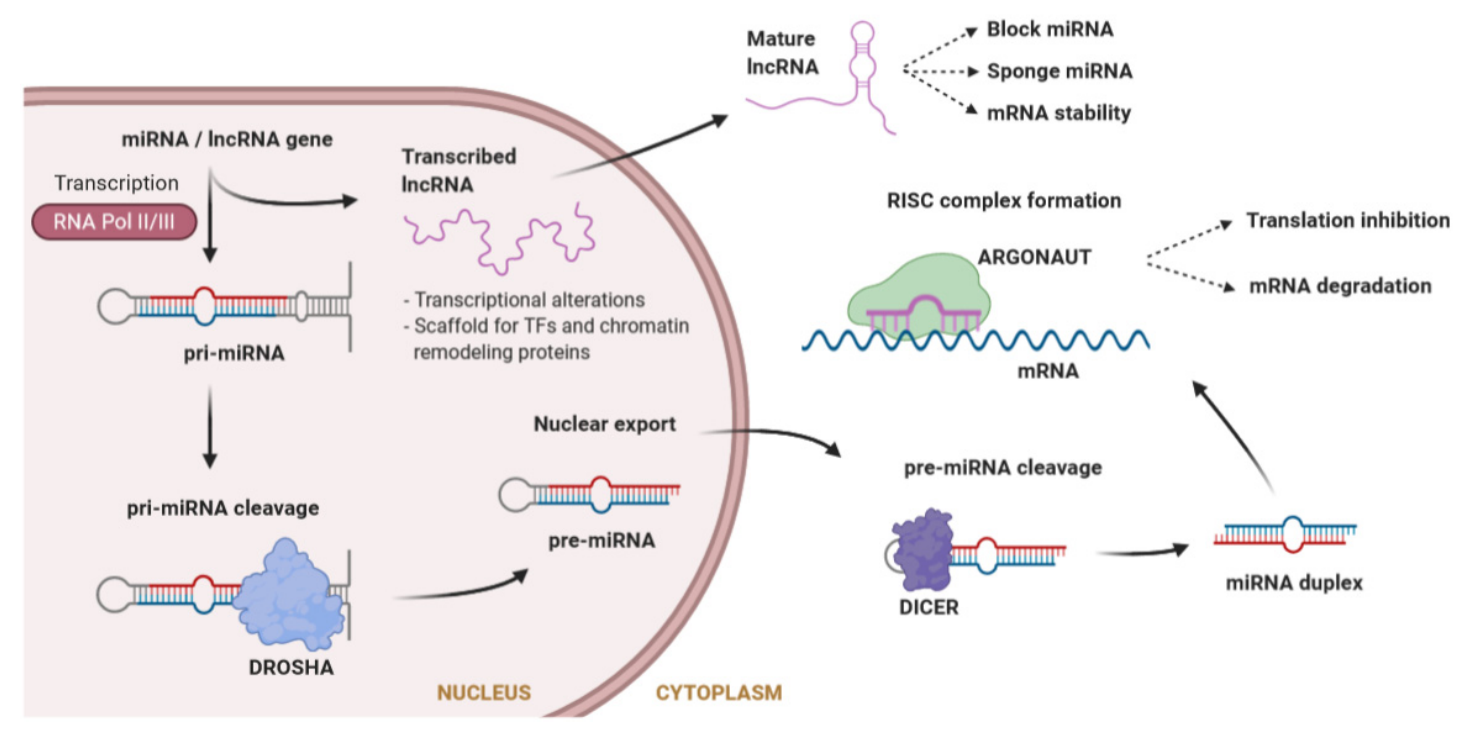

Figure 2. Synthesis of microRNAs (miRNAs) and long non-coding RNAs (lncRNAs), as well as mechanisms of action. miRNA biogenesis consists of a series of steps where a premature miRNA is cleaved until it reaches the mature form outside the nucleus. Both miRNAs and lncRNAs can interfere with gene regulation through different mechanisms. lncRNAs also interfere in the function of other miRNAs.

\subsection{Deciphering the Funtional Outcome of Non-Coding Variants}

In contrast to the study of coding variants, in which the analyses are focused on examining the effect of the variant in protein function, the interpretation of the functional impact of regulatory variants still remains a challenge. Although recent efforts to characterize non-coding sequences have identified many regulatory elements and clarified general aspects of gene regulation, a substantial gap remains between the identification of regulatory elements and a detailed understanding of their function [70].

Several computational algorithms have been developed to predict regulatory function and prioritize those non-coding variants that are more likely to have a functional impact [71,72], thereby minimizing the number of variants to be studied in functional assays [73]. The combined annotation-dependent depletion (CADD) score and context-dependent tolerance score (CDTS) are two examples of these computational tools. CADD score is the result of integrating diverse functional annotations into a score of deleteriousness, which strongly correlates with molecular functionality and variant effects [74]. In contrast, CDTS measures how tolerant genomic regions are to genetic variation in the context of surrounding sequences. CDTS is organized into percentiles, with regions found in the first percentile being the least tolerant to genetic variation. Those variants found in regions less tolerant to variation are presumed to have the highest functional impact [75]. Similarly, several algorithms have also been developed to assess the effect of variants in miRNAs. For example, the Vienna RNAfold algorithm predicts the effect of variants on the secondary structure and expression of the miRNA [76], calculating the energy changes of the thermodynamic ensemble of the secondary structure of miRNAs. Altogether, these computational algorithms represent useful pre-screening tools before performing 
functional assays. However, each algorithm focuses on different aspects of genome biology, which can result in heterogeneous predictions of variant pathogenicity. For this reason, it is recommended to use more than one predictor to select putative candidate variants.

Classically, the effects of cis-regulatory variants on gene expression have been studied one-by-one in reporter assays. These reporter assays are based on a plasmid expressing the luciferase gene under the control of a DNA regulatory region containing the variant of interest. After transfecting cells with the plasmid, luciferase activity is measured in order to assess the impact of the variant over cell function [77]. Although this method is still the gold standard for enhancer/promoter assays, only a limited number of candidate regulatory elements can be tested. In addition, it has to be taken into account that, in these assays, the activity of CREs is analyzed within a plasmid, and therefore, the influences of the three-dimensional (3D) chromatin structure (chromatin territories and boundaries) are missing. In the recent years, thanks to the advances in DNA sequencing, some of these limitations have been overcome by the development of a number of powerful, high-throughput assays for large-scale testing of enhancer activity, known as massive parallel reporter assays (MPRAs). These high-throughput reporter screenings, such as CRE analysis by sequencing (CRE-seq) or self-transcribing active regulatory region sequencing (STARR-seq), allow us to massively measure the activity of regulatory elements in a direct, quantitative, and genome-wide manner [78,79].

Since its discovery in 2007, the use of human-induced pluripotent stem cells (hiPSCs) has revolutionized the study of human diseases, as they have the potential to be differentiated into any human cell type [80]. hiPSCs are a versatile tool for exploring molecular and cellular phenotypes in wild-type and patient-derived cells. Cardiomyocytes from patient-derived hiPSCs (hiPSC-CMs) have been used as in vitro models for various inherited cardiac diseases, such as long QT syndrome (LQTS), BrS, or congenital heart disease [81]. However, hiPSC-CMs present several limitations. Differentiation protocols still result in immature cardiomyocytes with incomplete cardiac cell structure. Also, it may be difficult to compare results obtained from hiPSC-CMs, due to the variability produced by either reprogramming protocols used to obtain patient-derived hiPSCs, or the inherent patient-specific genetic background. In this regard, to overcome the effects of genetic background, cells derived from the same patient—-therefore showing identical genetic background (i.e., isogenic cells)—are being used. Variants of interest are introduced into these cells by Clustered Regularly Interspaced Short Palindromic Repeats (CRISPR)-Cas9 genome editing approaches, generating modified hiPSCs whose genomes only differ in the variants introduced [82].

\section{Non-Coding Variants Associated with Cardiac Disorders and ECG Traits}

GWAS have uncovered an important number of non-coding variants associated with cardiovascular diseases or traits. In fact, the GWAS catalog (https://www.ebi.ac.uk/gwas/) includes more than 50 GWAS publications for almost 300 specific cardiovascular traits [83]. These studies have also identified many loci specifically associated with arrhythmias and electrocardiogram (ECG)-related traits such as the QT, PR, or QRS interval durations [84-91].

The QT interval is the time between ventricular depolarization and repolarization, and is a heritable trait with predisposition to arrhythmias and SCD when its duration is altered. A prolongation of the QT interval has been associated with a higher mortality in patients with cardiovascular disease, but also in healthy populations [92]. An example of a non-coding variant associated with QT interval duration and cardiac repolarization, rs7539120, is located in an enhancer modulating the expression of NOS1AP [93,94]. Interestingly, rs7539120 overlaps a DNase I hypersensitivity site, and is associated with an overexpression of NOS1AP [93]. A GWAS conducted by Arking and colleagues also identified common variants in linkage disequilibrium (LD) associated with cardiac repolarization at the $5^{\prime}$ upstream region of NOS1AP gene [89]. These variants were shown to be strongly linked with the modulation of the QT interval in the general population, pointing to a previously unknown role of the nitric oxide synthase pathway in the heart function, later confirmed by other authors [95]. In addition, these common variants have also been shown to modulate the QT interval and risk of arrhythmia in 
LQTS patients [96,97]. Similarly, intronic and UTR common variants at the KCNQ1, KCNE1, KCNH2, and SCN5A genes have been associated with QT interval and myocardial repolarization [91,98].

PR interval and QRS duration are ECG parameters used to evaluate the risk of arrhythmia $[90,99]$. The PR interval measures the time an electrical impulse takes to travel from the atria to the ventricles (from the sinus node to the Purkinje fibers), and the QRS duration records the depolarization of the ventricles [88]. A prolongation of the PR interval has been associated with a higher risk of AF and mortality [100], while alterations in the QRS duration have been associated with a decrease in life expectancy [101]. In addition to coding variants, common non-coding variants in CDKN1A, TBX5, and DKK1 have been associated with alterations in QRS duration in GWAS [88,102]. For instance, a non-coding SNV located at the $3^{\prime}$ UTR at the SHOX2 gene, encoding a TF with a key role in the development of the sinoatrial node, has been associated with longer PR intervals [103]. This variant creates a novel binding site for the hsa-miR-92b-5p, reducing the expression of SHOX2, which promotes a proarrhythmogenic condition that could lead to AF [103]. Similarly, in a recent report, Vincentz and colleagues showed that rs10054375, located in a tissue-specific enhancer of Hand1, leads to severe abnormalities in the ventricular conduction system. Their studies demonstrated that this variant affects the binding site for GATA4, a master regulator of cardiac regulatory networks [104]. However, the region containing the SCN5A and SCN10A genes represents a major locus that consistently accumulates GWAS hits associated with the PR interval and QRS duration (see Section 5) [92].

In addition to arrhythmias, non-coding variants have also been associated with the pathogenesis of cardiomyopathies. For example, intronic variants in dystrophin, plakophilin, or MYBPC3 genes have been shown to disrupt alternative splicing and generate truncated proteins, leading to hypertrophic cardiomyopathy, dilated cardiomyopathy, and arrhythmogenic right ventricular cardiomyopathy [105]. Furthermore, miR-350, miR-206, miR-195, and miR-208 have been shown to be abnormally overexpressed in cardiac hypertrophy [106]. In contrast, overexpression of the lncRNA Mhrt has been associated with a protective effect in cardiac hypertrophy [107].

\section{Role of SCN5A Protein-Coding Variants in Brugada Syndrome}

To date, more than 350 rare variants associated with BrS have been described within the SCN5A coding regions [108,109], representing $20-25 \%$ of clinically diagnosed BrS cases [110]. These variants are scattered along the $\mathrm{Na}_{\mathrm{V}} 1.5$ protein, which consists of four homologous domains joined by so-called linkers, where each domain contains six transmembrane helices linked by intracellular or extracellular loops. Functional studies performed in in vitro expression systems have demonstrated that most of these variants lead to a reduction of the sodium current, either by affecting the functionality of the protein or the amount of channel in the cell membrane [3,111]. However, the exact mechanism that links the reduction of the sodium current with the BrS ECG pattern is still under discussion [112]. In addition to $S C N 5 A$, variants in the coding regions of other ion channel genes, such as sodium channel regulatory beta subunits $(S C N 1 B, S C N 2 B$, and $S C N 3 B)$ and calcium channels $(C A C N A 1 C$, CACNA2D1, and CACNB2) have also been described, and account for $5-10 \%$ of BrS cases. Variants in other genes have also been associated with the disease, although they represent a much lower incidence of BrS patients [5,113]. Although those genes are routinely tested for in BrS patients, a recent study by Hossein and colleagues showed that SCN5A is the only gene with definitive evidence to be used in clinical diagnosis [8].

A major challenge related to BrS genetics is the lack of correlation between genotype and phenotype. Only $20-25 \%$ of the BrS patients carry a SCN5A variant, and in those cases, there is a highly variable expressivity among the carriers, hindering the interpretation and relevance of variants [13]. Moreover, SCN5A variants have also been shown to have pleiotropic effects (i.e., they can be associated with different phenotypes) [20], as they have been associated with different cardiac arrhythmias, such as LQTS type 3, dilated cardiomyopathy, AF, and other conduction defects [114]. Some studies claim that the absence of coding SCN5A variants in BrS patients would be a signal of a benign BrS phenotype, and that these patients should not be catalogued as real BrS patients [115]. However, as mentioned 
above, several authors agree with the notion that the BrS phenotype would be determined by other factors beyond coding variants, including common variants found in non-coding regions from several loci, as well as environmental factors [15].

\section{Role of Non-Coding Variants in Brugada Syndrome}

\subsection{The SCN5A Promoter}

During the last years, there have been several studies suggesting that alterations in SCN5A gene expression may increase susceptibility to arrhythmogenic diseases, in particular BrS. For instance, Leoni and colleagues reported that mice expressing a single copy of the SCN5A gene show cardiac defects that resemble those observed in humans with BrS [116]. However, at present, the molecular mechanisms of SCN5A transcriptional regulation are still not well understood. In this regard, our laboratory has provided some insight into these mechanisms, by showing that GATA4 and GATA5 TFs co-occupy the $S C N 5 A$ promoter and the first intronic regions, and synergize in order to regulate the expression of the SCN5A gene in the human heart [117]. A recent report has also shown that IRX5 and GATA4 act synergistically to activate the $S C N 5 A$ promoter [118].

Different studies have identified a series of common SNVs in the SCN5A core promoter that are associated with alterations in the transcriptional activity of $S C N 5 A$. Bezzina and colleagues described three haplotypes (HapA-C) within the SCN5A promoter region, consisting of different combinations of six common SNVs in near-complete LD (rs41311113, rs9825294, rs41310241, rs41310239, rs41310237, and rs41310236) [102]. Luciferase reporter assays showed that HapB, common among the Japanese population, is associated with a significant decrease of the promoter activity. Interestingly, while the haplotype is present in $22 \%$ of the Japanese cohort, it is rare or absent in other populations, suggesting that the effects associated with this haplotype could be population-specific [102]. Another example was described by Yang and colleagues, who described a haplotype in the SCN5A promoter consisting of two common variants, rs41310749 and rs41310239 [119]. They observed that patients carrying the haplotype in heterozygosis with a loss-of-function SCN5A coding variant showed a more severe BrS phenotype [120], supporting the notion of a modulatory effect of non-coding variants on the severity of disease.

In the same line of evidence, Yang and colleagues described SNVs within the $5^{\prime}$ UTR, exon 1 , and intron 1 of SCN5A in a Caucasian BrS cohort. They also observed that these variants lie within TFBS and are affecting the binding of specific TFs. Similarly, a recent study by Yagihara and colleagues identified novel rare variants within the core region of the SCN5A promoter in BrS patients from Japanese origin, observing that three of these variants are associated with reduced promoter activity [121]. An interesting example of a SCN5A promoter variant is rs1805124, which has been described as a protective genetic modulator. This common variant has been shown to decrease the methylation rate of the promoter, thereby increasing SCN5A expression levels. As a result, rs1805124 carriers present ECG patterns with lower severity, enhanced sodium channel activity, and less frequent occurrence of ventricular fibrillation [122].

Altogether, these studies support the notion that variants in the SCN5A promoter, and especially those affecting TFBSs, can have an impact on $S C N 5 A$ gene expression and ECG parameters, and therefore modulate BrS pathogenesis.

\subsection{The SCN5A-SCN10A Locus}

GWAS conducted on ECG traits and cardiac conduction disorders have highlighted the association of the SCN5A-SCN10A locus to QRS duration and PR interval, suggesting a relevant role in cardiac conduction and heart function [84,85]. Remarkably, most of the variants identified in these studies are located in non-coding regions. While $S C N 5 A$ variants are well-known to be associated with cardiac arrhythmias, the identification of $S C N 10 A$ as a major risk region for ECG traits was intriguing. SCN10A encodes the alpha subunit of the sodium channel Nav1.8, originally described as being expressed in 
nociceptive sensory neurons and playing an important role in pain perception [123-125]. Later studies have shown that $\mathrm{Na}_{\mathrm{V}} 1.8$ contributes to cardiac electrophysiology, but the molecular mechanism is still under debate, especially regarding its expression in cardiomyocytes. A murine model reported that $\mathrm{Na}_{V} 1.8$ is present in intracardiac neurons, but not in ventricular cardiomyocytes [126]. Other studies have claimed that $\mathrm{Na}_{V} 1.8$ contributes to the late cardiac sodium current $[127,128]$, and suggested that $\mathrm{Na}_{V} 1.8$ could be involved in arrhythmogenesis [129]. However, a recent report showed the absence of functional $\mathrm{Na}_{V} 1.8$ channels in cardiac cells from rabbit and hiPSC-CMs [130].

Bezzina and colleagues provided more evidence for the relevance of the $S C N 5 A-S C N 10 A$ locus with the only GWAS performed on a BrS cohort, with 312 BrS patients of European ancestry. In their study, they identified three independent common variants (rs10428132, rs9388451, and rs11708996) in three different loci (SCN5A, SCN10A, and HEY2). The strongest association corresponded to rs10428132, a variant located within the intron 14 of the SCN10A gene [18]. The second strongest association, rs9388451, was detected downstream of HEY2, encoding a cardiac TF that regulates cardiac electric activity, and is possibly involved in the pathogenesis of $\mathrm{BrS}[18,131]$. The third strongest association, rs11708996, was located within an intronic region of SCN5A. This variant had already been previously linked to alterations in QRS and PR intervals, and thus to cardiac conduction [99,119]. Bezzina and colleagues showed that these three loci have a large cumulative effect on BrS risk, as patients carrying more than four risk alleles presented a stronger association to $\mathrm{BrS}$ compared with patients carrying fewer than two risk alleles. The authors also found that $1.5 \%$ of the European population is harboring more than four risk alleles, suggesting that these three common variants act as modulators of disease susceptibility rather than being causal variants [18].

Studies performed by Van den Boogaard and colleagues uncovered another possible role of SCN10A non-coding variants in conduction disorders. In particular, they showed that the SCN10A intronic variant rs6801957, identified in a GWAS associated with cardiac conduction disease, is located in an enhancer region that modulates the expression of SCN5A gene. Interestingly, they demonstrated that rs6801957 disrupts the binding of the T-box transcription factors 3 and 5 (TBX3/TBX5) to this $S C N 10 A$ intronic enhancer, resulting in reduced $S C N 5 A$ expression levels. Furthermore, they also showed that this variant is associated with decreased $S C N 5 A$ expression in homozygosis in left ventricle samples [132-134]. Man and colleagues have recently reasserted the crucial role of the SCN5A-SCN10A locus for the control of the gene activity and topology, through the study of a super enhancer cluster downstream of $S C N 5 A$. Interestingly, they found that all the interacting regulatory components in the locus are required for proper SCN5A expression and normal cardiac conduction. They also suggested that variants affecting the super enhancer cluster may affect the chromatin architecture of the SCN5A-SCN10A locus, and consequently, the expression of SCN5A [135].

In summary, the previously described studies demonstrate that the intronic region of SCN10A contributes to cardiac electrophysiology, and that non-coding variants within this region can be associated with BrS or other ECG traits [133]. However, the molecular basis underlying the effects of common variants in SCN10A is still unclear, since the role of $\mathrm{Na}_{\mathrm{v}} 1.8$ in cardiac function and its expression in cardiomyocytes remains controversial $[128,136]$. In conclusion, future studies should decipher whether the functional effect of these variants is related to dysregulation of SCN5A expression through the role of $S C N 10 A$ as an enhancer, the activity of $\mathrm{Na}_{V} 1.8$ in intracardiac neurons that regulate cardiac electric activity, or both.

\subsection{Non-Coding RNAs}

Over the past decade, miRNAs have been shown to play important roles in heart development and function. From those, miR-1, miR-25, miR-26, miR-29, and miR-328 have been specifically associated with cardiac arrhythmias [137-141]. Functional studies have demonstrated that miR-24, miR-98, miR-106, miR-200, miR-219, and miR-1270 regulate SCN5A expression [12,142-144], while miRNAs like miR-125 and miR-153 have been described as indirect regulators of SCN5A [142].

To date, there are only a few studies that have identified variants affecting the function of miRNAs that target $S C N 5 A$, and therefore could be associated with BrS. Daimi and colleagues identified two 
common variants (rs4073796 and rs4073797) within the SCN5A 3' UTR of a Tunisian family with $\mathrm{BrS}$, which is, to date, the major study linking miRNA-related variants with BrS [12]. In particular, they showed that together, rs4073797 and rs4073796 create an extra binding site for miR-1270, leading to downregulation of $S C N 5 A$ expression. The same study identified another common variant in the same family, rs107822, located $36 \mathrm{bp}$ upstream the miRNA-219 precursor sequence and potentially affecting the structure of the mature miRNA and, in consequence, SCN5A expression. A similar study by Song and colleagues confirmed these observations by detecting differential expression of mature miR-219 in the presence of rs107822 [145].

In regard to lncRNAs, it is important to highlight that regulation of BrS-associated genes MHY7, IRX5, and CACNA1C, has been linked with IncRNAs [146]. In particular, the lncRNA cluster Myheart has been associated with the regulation of $M H Y 7$ through the interaction with chromatin remodelling factors, and has been reported to be significantly elevated in patients with acute myocardial infarction [107]. Other lncRNAs have been described as being associated with inherited arrhythmogenic diseases, such as AF [147]. One example is the so-called KCNQ1OT1, an lncRNA that regulates CACNA1C expression through the sponging of miR-384, leading to alterations in the electrophysiological parameters [148]. In agreement with this data, KCNQ1OT1 silencing has been associated with a lower incidence of AF. Intriguingly, multiple lncRNAs have been found to be differentially expressed in AF patients, although their target genes and function are still unknown $[149,150]$. Altogether, these observations suggest that non-coding variants affecting the function of lncRNAs could also explain the molecular basis of cardiac arrhythmias in which the etiology is still unknown, including BrS.

\section{Conclusions}

Almost 30 years since the clinical description of BrS, multiple studies have been carried out in order to elucidate both the genetic basis and the pathophysiology of BrS. Despite the great advances in this field, there is still a knowledge gap that needs to be addressed before reaching a reliable understanding of the inheritance and the significance of BrS-associated variants.

During the last years, a growing body of evidence suggests that non-coding regulatory variants may play an important role in BrS susceptibility by modulating its phenotype. Many of these studies have identified variants in the SCN5A-SCN10A locus, which may be affecting SCN5A and/or SCN10A expression levels in the heart (Figure $3 \mathrm{~A}, \mathrm{~B}$ ). However, a better understanding of the mechanisms explaining how dysregulation of SCN5A and/or SCN10A expression is linked to alterations in ECGs and cardiac arrhythmias is still missing. At the same time, only a few studies have focused on examining the potential role of miRNAs in BrS pathogenesis, although their findings strongly suggest that variants within the SCN5A 3' UTR or miRNAs could be associated with alterations in SCN5A expression and BrS pathogenesis (Figure $3 \mathrm{C}$ ).

In this scenario, deciphering the effect of non-coding variants associated with BrS will be critical to further understand the genetic basis of this cardiac disorder, although challenging. The problems encountered by researchers in assessing the role of non-coding variants using hiPSC models are currently difficult to overcome with alternative methods. Murine, porcine, and canine models have been used in the past to study SCN5A variants associated with BrS [151]. However, we have to take into account that these models present differences in electrophysiological properties, ion channel expression profiles, or reproductive cycles, and may lead to findings that may not be relevant in humans. Beyond the use of in vitro or in vivo models, we suggest that population studies could be a fine method to better assess the role of common non-coding variants in modulating ECG traits. In this regard, studies of healthy individuals harboring common variants associated with BrS may uncover novel roles of non-coding variants in the regulation of cardiac function.

Even though SCN5A is the principal contributing factor to BrS, all the observations aforementioned support the growing hypothesis that $\mathrm{BrS}$ pathogenesis follows an oligogenic or multigenic model $[15,20,114,115]$. Based on this model, we also propose that BrS may not be caused by a single 
pathogenic variant, but rather by the presence of multiple susceptibility variants acting synergistically through one or more mechanistic pathways.

In this review, we aimed at pinpointing the increasing evidence suggesting an important role of non-coding variants in modulating BrS susceptibility, and encourage the increase of efforts in the study of non-coding variants, in order to further our understanding of this cardiac disorder.

\section{A. SCN5A Promoter Variants}

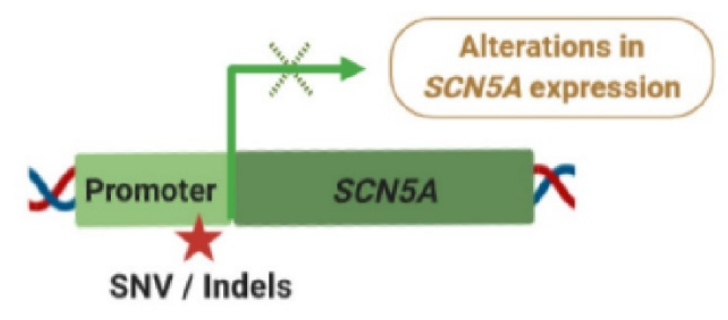

B. SCN10A Variants

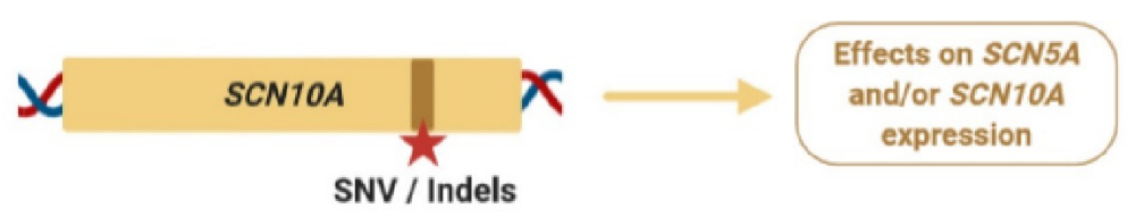

C. miRNA Variants

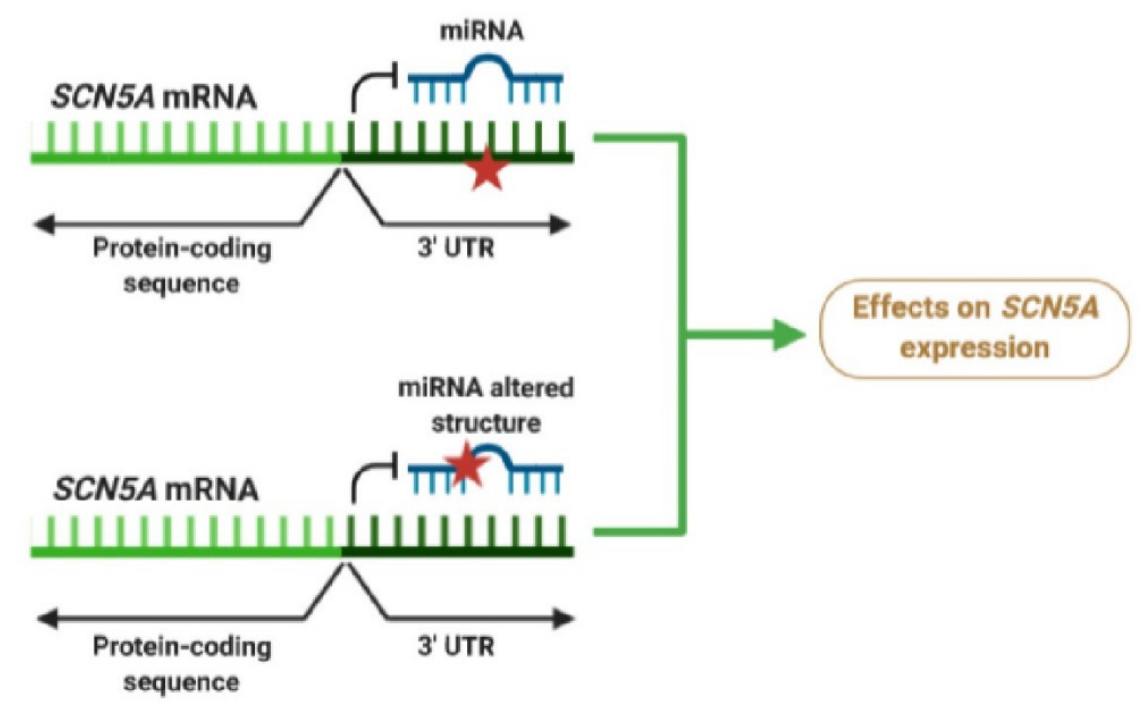

Figure 3. Potential effects of non-coding variants associated with Brugada syndrome (BrS). (A) Variants in the $S C N 5 A$ promoter can lead to alterations in its mRNA expression levels. (B) Intronic variants in $S C N 10 A$ could be affecting $S C N 5 A$ expression through an enhancer-mediated mechanism or affecting the activity of SCN10A. (C) Variants within the $3^{\prime}$ untranslated region (UTR) of SCN5A, or affecting the function of BrS-related miRNAs, could lead to dysregulation of SCN5A expression. Red star indicates the position of a new single nucleotide variant $(\mathrm{SNV})$ or an insertion/deletion (Indel). Green $\times$ indicates possible alterations of gene expression.

Author Contributions: Writing — original draft preparation, A.P.-A.; conceptualization, draft revision, and editing, M.P.-A., S.P. All authors have read and agreed to the publish version of the manuscript. 
Funding: This work was supported by funding provided to S.P. form the Spanish Government (SAF2015-70823-R, MINECO/FEDER, UE). A.P.-A. acknowledges a predoctoral fellowship from Generalitat de Catalunya (2018FI_B 00445) and the European Social Fund (ESF).

Acknowledgments: We thank Sara Veiga from the Centro de Investigación en Medicina Molecular y Enfermedades Crónicas (CiMUS), USC) for reading the manuscript and helpful comments.

Conflicts of Interest: The authors declare no conflict of interest.

\section{References}

1. Brugada, P.; Brugada, J. Right bundle branch block, persistent ST segment elevation and sudden cardiac death: A distinct clinical and electrocardiographic syndrome. A multicenter report. J. Am. Coll. Cardiol. 1992, 20, 1391-1396. [CrossRef]

2. Morita, H.; Kusano-Fukushima, K.; Nagase, S.; Fujimoto, Y.; Hisamatsu, K.; Fujio, H.; Haraoka, K.; Kobayashi, M.; Morita, S.T.; Nakamura, K.; et al. Atrial fibrillation and atrial vulnerability in patients with Brugada syndrome. J. Am. Coll. Cardiol. 2002, 40, 1437-1444. [CrossRef]

3. Kapplinger, J.D.; Tester, D.J.; Alders, M.; Benito, B.; Berthet, M.; Brugada, J.; Brugada, P.; Fressart, V.; Guerchicoff, A.; Harris-Kerr, C.; et al. An international compendium of mutations in the SCN5A-encoded cardiac sodium channel in patients referred for Brugada syndrome genetic testing. Hear. Rhythm 2010, 7 , 33-46. [CrossRef] [PubMed]

4. Snir, A.D.; Raju, H. Current Controversies and Challenges in Brugada Syndrome. Eur. Cardiol. Rev. 2019, 14, 169-174. [CrossRef] [PubMed]

5. Riuró, H.; Beltran-Alvarez, P.; Tarradas, A.; Selga, E.; Campuzano, O.; Vergés, M.; Pagans, S.; Iglesias, A.; Brugada, J.; Brugada, P.; et al. A Missense Mutation in the Sodium Channel $\beta 2$ Subunit Reveals SCN2B as a New Candidate Gene for Brugada Syndrome. Hum. Mutat. 2013, 34, 961-966. [CrossRef] [PubMed]

6. Hu, D.; Barajas-Martinez, H.; Burashnikov, E.; Springer, M.; Wu, Y.; Varro, A.; Pfeiffer, R.; Koopmann, T.T.; Cordeiro, J.M.; Guerchicoff, A.; et al. A mutation in the $\beta 3$ subunit of the cardiac sodium channel associated with brugada ECG phenotype. Circ. Cardiovasc. Genet. 2009, 2, 270-278. [CrossRef]

7. Antzelevitch, C.; Pollevick, G.D.; Cordeiro, J.M.; Casis, O.; Sanguinetti, M.C.; Aizawa, Y.; Guerchicoff, A.; Pfeiffer, R.; Oliva, A.; Wollnik, B.; et al. Loss-of-function mutations in the cardiac calcium channel underlie a new clinical entity characterized by ST-segment elevation, short QT intervals, and sudden cardiac death. Circulation 2007, 115, 442-449. [CrossRef]

8. Hosseini, S.M.; Kim, R.; Udupa, S.; Costain, G.; Jobling, R.; Liston, E.; Jamal, S.M.; Szybowska, M.; Morel, C.F.; Bowdin, S.; et al. Reappraisal of reported genes for sudden arrhythmic death: Evidence-based evaluation of gene validity for brugada syndrome. Circulation 2018, 138, 1195-1205. [CrossRef]

9. Priori, S.G.; Napolitano, C.; Gasparini, M.; Pappone, C.; Della Bella, P.; Brignole, M.; Giordano, U.; Giovannini, T.; Menozzi, C.; Bloise, R.; et al. Clinical and genetic heterogeneity of right bundle branch block and ST-segment elevation syndrome: A prospective evaluation of 52 families. Circulation 2000, 102, 2509-2515. [CrossRef]

10. Probst, V.; Wilde, A.A.M.; Barc, J.; Sacher, F.; Babuty, D.; Mabo, P.; Mansourati, J.; Le Scouarnec, S.; Kyndt, F.; Le Caignec, C.; et al. SCN5A Mutations and the role of genetic background in the pathophysiology of brugada syndrome. Circ. Cardiovasc. Genet. 2009, 2, 552-557. [CrossRef]

11. Saber, S.; Amarouch, M.Y.; Fazelifar, A.F.; Haghjoo, M.; Emkanjoo, Z.; Alizadeh, A.; Houshmand, M.; Gavrilenko, A.V.; Abriel, H.; Zaklyazminskaya, E.V. Complex genetic background in a large family with Brugada syndrome. Physiol. Rep. 2015, 3, 1-7. [CrossRef] [PubMed]

12. Daimi, H.; Khelil, A.H.; Neji, A.; Hamda, K.B.; Maaoui, S.; Aranega, A.; Chibani, J.B.; Franco, D. Role of SCN5A coding and non-coding sequences in Brugada syndrome onset: What's behind the scenes? Biomed. J. 2019, 42, 252-260. [CrossRef] [PubMed]

13. Juang, J.M.J.; Horie, M. Genetics of Brugada syndrome. J. Arrhythmia 2016, 32, 418-425. [CrossRef] [PubMed]

14. Olivotto, I.; Coppini, R. Channelopathies, cardiac hypertrophy, and the theory of light. Eur. Heart J. 2018, 39, 2908-2910. [CrossRef]

15. Monasky, M.M.; Micaglio, E.; Ciconte, G.; Pappone, C. Brugada syndrome: Oligogenic or mendelian disease? Int. J. Mol. Sci. 2020, 21, 1687. [CrossRef]

16. Maurano, M.T.; Humbert, R.; Rynes, E.; Thurman, R.E.; Haugen, E.; Wang, H.; Reynolds, A.P.; Sandstrom, R.; $\mathrm{Qu}, \mathrm{H}$.; Brody, J.; et al. Systematic localization of common disease-associated variation in regulatory DNA. Science 2012, 337, 1190-1195. [CrossRef] 
17. Telenti, A.; Pierce, L.C.T.; Biggs, W.H.; Di Iulio, J.; Wong, E.H.M.; Fabani, M.M.; Kirkness, E.F.; Moustafa, A.; Shah, N.; Xie, C.; et al. Deep sequencing of 10,000 human genomes. Proc. Natl. Acad. Sci. USA 2016, 113, 11901-11906. [CrossRef]

18. Bezzina, C.R.; Barc, J.; Mizusawa, Y.; Remme, C.A.; Gourraud, J.B.; Simonet, F.; Verkerk, A.O.; Schwartz, P.J.; Crotti, L.; Dagradi, F.; et al. Common variants at SCN5A-SCN10A and HEY2 are associated with Brugada syndrome, a rare disease with high risk of sudden cardiac death. Nat. Genet. 2013, 45, 1044-1049. [CrossRef]

19. Gibson, G. Rare and common variants: Twenty arguments. Nat. Rev. Genet. 2012, 13, 135-145. [CrossRef]

20. Cerrone, M.; Remme, C.A.; Tadros, R.; Bezzina, C.R.; Delmar, M. Beyond the one gene-one disease paradigm complex genetics and pleiotropy in inheritable cardiac disorders. Circulation 2019, 140, 595-610. [CrossRef]

21. Auton, A.; Abecasis, G.R.; Altshuler, D.M.; Durbin, R.M.; Bentley, D.R.; Chakravarti, A.; Clark, A.G.; Donnelly, P.; Eichler, E.E.; Flicek, P.; et al. A global reference for human genetic variation. Nature 2015, 526, 68-74. [PubMed]

22. Lupski, J.R.; Belmont, J.W.; Boerwinkle, E.; Gibbs, R.A. Clan genomics and the complex architecture of human disease. Cell 2011, 147, 32-43. [CrossRef] [PubMed]

23. Corradin, O.; Saiakhova, A.; Akhtar-Zaidi, B.; Myeroff, L.; Willis, J.; Cowper-Sallari, R.; Lupien, M.; Markowitz, S.; Scacheri, P.C. Combinatorial effects of multiple enhancer variants in linkage disequilibrium dictate levels of gene expression to confer susceptibility to common traits. Genome Res. 2014, 24, 1-13. [CrossRef] [PubMed]

24. Marangoni, S.; Di Resta, C.; Rocchetti, M.; Barile, L.; Rizzetto, R.; Summa, A.; Severi, S.; Sommariva, E.; Pappone, C.; Ferrari, M.; et al. A Brugada syndrome mutation (p.S216L) and its modulation by p.H558R polymorphism: Standard and dynamic characterization. Cardiovasc. Res. 2011, 91, 606-616. [CrossRef] [PubMed]

25. Lek, M.; Karczewski, K.J.; Minikel, E.V.; Samocha, K.E.; Banks, E.; Fennell, T.; O’Donnell-Luria, A.H.; Ware, J.S.; Hill, A.J.; Cummings, B.B.; et al. Analysis of protein-coding genetic variation in 60,706 humans. Nature 2016, 536, 285-291. [CrossRef] [PubMed]

26. Sakabe, N.J.; Savic, D.; Nobrega, M.A. Transcriptional enhancers in development and disease. Genome Biol. 2012, 13, 1-11. [CrossRef]

27. Lee, T.I.; Young, R.A. Transcriptional regulation and its misregulation in disease. Cell 2013, 152, $1237-1251$. [CrossRef]

28. Pennacchio, L.A.; Bickmore, W.; Dean, A.; Nobrega, M.A.; Bejerano, G. Enhancers: Five essential questions. Nat. Rev. Genet. 2013, 14, 288-295. [CrossRef]

29. Juven-Gershon, T.; Kadonaga, J.T. Regulation of gene expression via the core promoter and the basal transcriptional machinery. Dev. Biol. 2010, 339, 225-229. [CrossRef]

30. Dixon, J.R.; Gorkin, D.U.; Ren, B. Chromatin Domains: The Unit of Chromosome Organization. Mol. Cell 2016, 62, 668-680. [CrossRef]

31. Dixon, J.R.; Selvaraj, S.; Yue, F.; Kim, A.; Li, Y.; Shen, Y.; Hu, M.; Liu, J.S.; Ren, B. Topological domains in mammalian genomes identified by analysis of chromatin interactions. Nature 2012, 485, 376-380. [CrossRef] [PubMed]

32. Spielmann, M.; Mundlos, S. Looking beyond the genes: The role of non-coding variants in human disease. Hum. Mol. Genet. 2016, 25, R157-R165. [CrossRef] [PubMed]

33. Khurana, E.; Fu, Y.; Chakravarty, D.; Demichelis, F.; Rubin, M.A.; Gerstein, M. Role of non-coding sequence variants in cancer. Nat. Rev. Genet. 2016, 17, 93-108. [CrossRef] [PubMed]

34. Keung, A.J.; Joung, J.K.; Khalil, A.S.; Collins, J.J. Chromatin regulation at the frontier of synthetic biology. Nat. Rev. Genet. 2015, 16, 159-171. [CrossRef]

35. De Gobbi, M.; Viprakasit, V.; Hughes, J.R.; Fisher, C.; Buckle, V.J.; Ayyub, H.; Gibbons, R.J.; Vernimmen, D.; Yoshinaga, Y.; De Jong, P.; et al. A regulatory SNP causes a human genetic disease by creating a new transcriptional promoter. Science 2006, 312, 1215-1217. [CrossRef]

36. Donaghey, J.; Thakurela, S.; Charlton, J.; Chen, J.S.; Smith, Z.D.; Gu, H.; Pop, R.; Clement, K.; Stamenova, E.K.; Karnik, R.; et al. Genetic determinants and epigenetic effects of pioneer-factor occupancy. Nat. Genet. 2018, 50, 250-258. [CrossRef]

37. Waszak, S.M.; Delaneau, O.; Gschwind, A.R.; Kilpinen, H.; Raghav, S.K.; Witwicki, R.M.; Orioli, A.; Wiederkehr, M.; Panousis, N.I.; Yurovsky, A.; et al. Population Variation and Genetic Control of Modular Chromatin Architecture in Humans. Cell 2015, 162, 1039-1050. [CrossRef] 
38. Arzate-Mejía, R.G.; Josué Cerecedo-Castillo, A.; Guerrero, G.; Furlan-Magaril, M.; Recillas-Targa, F. In situ dissection of domain boundaries affect genome topology and gene transcription in Drosophila. Nat. Commun. 2020, 11, 1-6. [CrossRef]

39. Narendra, V.; Rocha, P.P.; An, D.; Raviram, R.; Skok, J.A.; Mazzoni, E.O.; Reinberg, D. CTCF establishes discrete functional chromatin domains at the Hox clusters during differentiation. Science 2015, 347, 1017-1021. [CrossRef]

40. Katainen, R.; Dave, K.; Pitkänen, E.; Palin, K.; Kivioja, T.; Välimäki, N.; Gylfe, A.E.; Ristolainen, H.; Hänninen, U.A.; Cajuso, T.; et al. CTCF/cohesin-binding sites are frequently mutated in cancer. Nat. Genet. 2015, 47, 818-821. [CrossRef]

41. Hnisz, D.; Weintrau, A.S.; Day, D.S.; Valton, A.L.; Bak, R.O.; Li, C.H.; Goldmann, J.; Lajoie, B.R.; Fan, Z.P.; Sigova, A.A.; et al. Activation of proto-oncogenes by disruption of chromosome neighborhoods. Science 2016, 351, 1454-1458. [CrossRef] [PubMed]

42. Sandelin, A.; Alkema, W.; Engström, P.; Wasserman, W.W.; Lenhard, B. JASPAR: An open-access database for eukaryotic transcription factor binding profiles. Nucleic Acids Res. 2004, 32. [CrossRef] [PubMed]

43. Machanick, P.; Bailey, T.L. MEME-ChIP: Motif analysis of large DNA datasets. Bioinformatics 2011, 27, 1696-1697. [CrossRef] [PubMed]

44. Telenti, A.; di Iulio, J. Regulatory genome variants in human susceptibility to infection. Hum. Genet. 2019, 139, 759-768. [CrossRef]

45. Osterwalder, M.; Barozzi, I.; Tissiéres, V.; Fukuda-Yuzawa, Y.; Mannion, B.J.; Afzal, S.Y.; Lee, E.A.; Zhu, Y.; Plajzer-Frick, I.; Pickle, C.S.; et al. Enhancer redundancy provides phenotypic robustness in mammalian development. Nature 2018, 554, 239-243. [CrossRef]

46. Farley, E.K.; Olson, K.M.; Zhang, W.; Rokhsar, D.S.; Levine, M.S. Syntax compensates for poor binding sites to encode tissue specificity of developmental enhancers. Proc. Natl. Acad. Sci. USA 2016, 113, 6508-6513. [CrossRef]

47. Dhamija, S.; Menon, M.B. Non-coding transcript variants of protein-coding genes-what are they good for? RNA Biol. 2018, 15, 1025-1031. [CrossRef]

48. Anastasiadou, E.; Jacob, L.S.; Slack, F.J. Non-coding RNA networks in cancer. Nat. Rev. Cancer 2017, 18, 5-18. [CrossRef]

49. Kozomara, A.; Griffiths-Jones, S. MiRBase: Integrating microRNA annotation and deep-sequencing data. Nucleic Acids Res. 2011, 39, D152. [CrossRef]

50. De Sousa, M.C.; Gjorgjieva, M.; Dolicka, D.; Sobolewski, C.; Foti, M. Deciphering miRNAs' action through miRNA editing. Int. J. Mol. Sci. 2019, 20, 6249. [CrossRef]

51. King, V.M.; Borchert, G.M. MicroRNA expression: Protein participants in microRNA regulation. Methods Mol. Biol. 2017, 1617, 27-37. [CrossRef] [PubMed]

52. Makrythanasis, P.; Antonarakis, S. Pathogenic variants in non-protein-coding sequences. Clin. Genet. 2013, 84, 422-428. [CrossRef] [PubMed]

53. Poller, W.; Dimmeler, S.; Heymans, S.; Zeller, T.; Haas, J.; Karakas, M.; Leistner, D.M.; Jakob, P.; Nakagawa, S.; Blankenberg, S.; et al. Non-coding RNAs in cardiovascular diseases: Diagnostic and therapeutic perspectives. Eur. Heart J. 2018, 39, 2704-2716. [CrossRef] [PubMed]

54. Boon, R.A.; Iekushi, K.; Lechner, S.; Seeger, T.; Fischer, A.; Heydt, S.; Kaluza, D.; Tréguer, K.; Carmona, G.; Bonauer, A.; et al. MicroRNA-34a regulates cardiac ageing and function. Nature 2013, 495, 107-110. [CrossRef] [PubMed]

55. Romaine, S.P.R.; Tomaszewski, M.; Condorelli, G.; Samani, N.J. MicroRNAs in cardiovascular disease: An introduction for clinicians. Heart 2015, 101, 921-928. [CrossRef] [PubMed]

56. Wojciechowska, A.; Braniewska, A.; Kozar-Kamińska, K. MicroRNA in cardiovascular biology and disease. Adv. Clin. Exp. Med. 2017, 26, 865-874. [CrossRef]

57. Kim, G.H. MicroRNA regulation of cardiac conduction and arrhythmias. Transl. Res. 2013, 161, $381-392$. [CrossRef]

58. Batista, P.J.; Chang, H.Y. Long noncoding RNAs: Cellular address codes in development and disease. Cell 2013, 152, 1298-1307. [CrossRef]

59. Robinson, E.K.; Covarrubias, S.; Carpenter, S. The how and why of lncRNA function: An innate immune perspective. Biochim. Biophys. Acta Gene Regul. Mech. 2020, 1863, 194419. [CrossRef] 
60. Kataoka, M.; Huang, Z.P.; Wang, D.Z. Build a braveheart: The missing linc (RNA). Circ. Res. 2013, 112, 1532-1534. [CrossRef]

61. Klattenhoff, C.A.; Scheuermann, J.C.; Surface, L.E.; Bradley, R.K.; Fields, P.A.; Steinhauser, M.L.; Ding, H.; Butty, V.L.; Torrey, L.; Haas, S.; et al. Braveheart, a long noncoding RNA required for cardiovascular lineage commitment. Cell 2013, 152, 570-583. [CrossRef] [PubMed]

62. Grote, P.; Wittler, L.; Hendrix, D.; Koch, F.; Währisch, S.; Beisaw, A.; Macura, K.; Bläss, G.; Kellis, M.; Werber, M.; et al. The Tissue-Specific lncRNA Fendrr Is an Essential Regulator of Heart and Body Wall Development in the Mouse. Dev. Cell 2013, 24, 206-214. [CrossRef] [PubMed]

63. Sauvageau, M.; Goff, L.A.; Lodato, S.; Bonev, B.; Groff, A.F.; Gerhardinger, C.; Sanchez-Gomez, D.B.; Hacisuleyman, E.; Li, E.; Spence, M.; et al. Multiple knockout mouse models reveal lincRNAs are required for life and brain development. eLife 2013, 2, e01749. [CrossRef] [PubMed]

64. Kataoka, M.; Wang, D.-Z. Non-Coding RNAs Including miRNAs and lncRNAs in Cardiovascular Biology and Disease. Cells 2014, 3, 883-898. [CrossRef] [PubMed]

65. Yang, K.C.; Yamada, K.A.; Patel, A.Y.; Topkara, V.K.; George, I.; Cheema, F.H.; Ewald, G.A.; Mann, D.L.; Nerbonne, J.M. Deep RNA sequencing reveals dynamic regulation of myocardial noncoding RNAs in failing human heart and remodeling with mechanical circulatory support. Circulation 2014, 129, 1009-1021. [CrossRef]

66. Ounzain, S.; Micheletti, R.; Beckmann, T.; Schroen, B.; Alexanian, M.; Pezzuto, I.; Crippa, S.; Nemir, M.; Sarre, A.; Johnson, R.; et al. Genome-wide profiling of the cardiac transcriptome after myocardial infarction identifies novel heart-specific long non-coding RNAs. Eur. Heart J. 2015, 36, 353-368. [CrossRef]

67. Kumarswamy, R.; Bauters, C.; Volkmann, I.; Maury, F.; Fetisch, J.; Holzmann, A.; Lemesle, G.; De Groote, P.; Pinet, F.; Thum, T. Circulating long noncoding RNA, LIPCAR, predicts survival in patients with heart failure. Circ. Res. 2014, 114, 1569-1575. [CrossRef]

68. Broadbent, H.M.; Peden, J.F.; Lorkowski, S.; Goel, A.; Ongen, H.; Green, F.; Clarke, R.; Collins, R.; Franzosi, M.G.; Tognoni, G.; et al. Susceptibility to coronary artery disease and diabetes is encoded by distinct, tightly linked SNPs in the ANRIL locus on chromosome 9p. Hum. Mol. Genet. 2008, 17, 806-814. [CrossRef]

69. Ishii, N.; Ozaki, K.; Sato, H.; Mizuno, H.; Saito, S.; Takahashi, A.; Miyamoto, Y.; Ikegawa, S.; Kamatani, N.; Hori, M.; et al. Identification of a novel non-coding RNA, MIAT, that confers risk of myocardial infarction. J. Hum. Genet. 2006, 51, 1087-1099. [CrossRef]

70. Zhang, F.; Lupski, J.R. Non-coding genetic variants in human disease. Hum. Mol. Genet. 2015, 24, R102-R110. [CrossRef]

71. Alipanahi, B.; Delong, A.; Weirauch, M.T.; Frey, B.J. Predicting the sequence specificities of DNA- and RNA-binding proteins by deep learning. Nat. Biotechnol. 2015, 33, 831-838. [CrossRef] [PubMed]

72. Kircher, M.; Shendure, J. Running spell-check to identify regulatory variants. Nat. Genet. 2015, 47, 853-855. [CrossRef] [PubMed]

73. Gelfman, S.; Wang, Q.; McSweeney, K.M.; Ren, Z.; La Carpia, F.; Halvorsen, M.; Schoch, K.; Ratzon, F.; Heinzen, E.L.; Boland, M.J.; et al. Annotating pathogenic non-coding variants in genic regions. Nat. Commun. 2017, 8, 1-10. [CrossRef] [PubMed]

74. Kircher, M.; Witten, D.M.; Jain, P.; O'roak, B.J.; Cooper, G.M.; Shendure, J. A general framework for estimating the relative pathogenicity of human genetic variants. Nat. Genet. 2014, 46, 310-315. [CrossRef]

75. Di Iulio, J.; Bartha, I.; Wong, E.H.M.; Yu, H.C.; Lavrenko, V.; Yang, D.; Jung, I.; Hicks, M.A.; Shah, N.; Kirkness, E.F.; et al. The human noncoding genome defined by genetic diversity. Nat. Genet. 2018, 50, 333-337. [CrossRef]

76. Ghanbari, M.; Iglesias, A.I.; Springelkamp, H.; van Duijn, C.M.; Ikram, M.A.; Dehghan, A.; Erkeland, S.J.; Klaver, C.C.W.; Meester-Smoor, M.A. A genome-wide scan for microrna-related genetic variants associated with primary open-angle glaucoma. Investig. Ophthalmol. Vis. Sci. 2017, 58, 5368-5377. [CrossRef]

77. Clément, T.; Salone, V.; Rederstorff, M. Dual luciferase gene reporter assays to study miRNA Function. Methods Mol. Biol. 2015, 1296, 187-198. [CrossRef]

78. Kwasnieski, J.C.; Mogno, I.; Myers, C.A.; Corbo, J.C.; Cohen, B.A. Complex effects of nucleotide variants in a mammalian cis-regulatory element. Proc. Natl. Acad. Sci. USA 2012, 109, 19498-19503. [CrossRef]

79. Muerdter, F.; Boryń, Ł.M.; Arnold, C.D. STARR-seq-Principles and applications. Genomics 2015, 106, 145-150. [CrossRef] 
80. Takahashi, K.; Tanabe, K.; Ohnuki, M.; Narita, M.; Ichisaka, T.; Tomoda, K.; Yamanaka, S. Induction of pluripotent stem cells from adult human fibroblasts by defined factors. Cell 2007, 131, 861-872. [CrossRef]

81. Selga, E.; Sendfeld, F.; Martinez-Moreno, R.; Medine, C.N.; Tura-Ceide, O.; Wilmut, S.I.; Pérez, G.J.; Scornik, F.S.; Brugada, R.; Mills, N.L. Sodium channel current loss of function in induced pluripotent stem cell-derived cardiomyocytes from a Brugada syndrome patient. J. Mol. Cell. Cardiol. 2018, 114, 10-19. [CrossRef] [PubMed]

82. Ben Jehuda, R.; Shemer, Y.; Binah, O. Genome Editing in Induced Pluripotent Stem Cells using CRISPR/Cas9. Stem Cell Rev. Rep. 2018, 14, 323-336. [CrossRef] [PubMed]

83. GWAS Catalog. Available online: https://www.ebi.ac.uk/gwas/home (accessed on 20 September 2020).

84. Sotoodehnia, N.; Isaacs, A.; De Bakker, P.I.W.; DÖrr, M.; Newton-Cheh, C.; Nolte, I.M.; Van Der Harst, P.; Müller, M.; Eijgelsheim, M.; Alonso, A.; et al. Common variants in 22 loci are associated with QRS duration and cardiac ventricular conduction. Nat. Genet. 2010, 42, 1068-1076. [CrossRef] [PubMed]

85. Chambers, J.C.; Zhao, J.; Terracciano, C.M.N.; Bezzina, C.R.; Zhang, W.; Kaba, R.; Navaratnarajah, M.; Lotlikar, A.; Sehmi, J.S.; Kooner, M.K.; et al. Genetic variation in SCN10A influences cardiac conduction. Nat. Genet. 2010, 42, 149-152. [CrossRef] [PubMed]

86. Pfeufer, A.; Sanna, S.; Arking, D.E.; Müller, M.; Gateva, V.; Fuchsberger, C.; Ehret, G.B.; Orr, M.; Pattaro, C.; Köttgen, A.; et al. Common variants at ten loci modulate the QT interval duration in the QTSCD Study. Nat. Genet. 2009, 41, 407-414. [CrossRef] [PubMed]

87. Knight, J.C. Approaches for establishing the function of regulatory genetic variants involved in disease. Genome Med. 2014, 6, 1-15. [CrossRef]

88. Holm, H.; Gudbjartsson, D.F.; Arnar, D.O.; Thorleifsson, G.; Thorgeirsson, G.; Stefansdottir, H.; Gudjonsson, S.A.; Jonasdottir, A.; Mathiesen, E.B.; Njølstad, I.; et al. Several common variants modulate heart rate, PR interval and QRS duration. Nat. Genet. 2010, 42, 117-122. [CrossRef]

89. Arking, D.E.; Pulit, S.L.; Crotti, L.; Van Der Harst, P.; Munroe, P.B.; Koopmann, T.T.; Sotoodehnia, N.; Rossin, E.J.; Morley, M.; Wang, X.; et al. Genetic association study of QT interval highlights role for calcium signaling pathways in myocardial repolarization. Nat. Genet. 2014, 46, 826-836. [CrossRef]

90. Gustav Smith, J.; Lowe, J.K.; Kovvali, S.; Maller, J.B.; Salit, J.; Daly, M.J.; Stoffel, M.; Altshuler, D.M.; Friedman, J.M.; Breslow, J.L.; et al. Genome-wide association study of electrocardiographic conduction measures in an isolated founder population: Kosrae. Heart Rhythm. 2009, 6, 634-641. [CrossRef]

91. Newton-Cheh, C.; Eijgelsheim, M.; Rice, K.M.; De Bakker, P.I.W.; Yin, X.; Estrada, K.; Bis, J.C.; Marciante, K.; Rivadeneira, F.; Noseworthy, P.A.; et al. Common variants at ten loci influence QT interval duration in the QTGEN Study. Nat. Genet. 2009, 41, 399-406. [CrossRef]

92. Buniello, A.; Macarthur, J.A.L.; Cerezo, M.; Harris, L.W.; Hayhurst, J.; Malangone, C.; McMahon, A.; Morales, J.; Mountjoy, E.; Sollis, E.; et al. The NHGRI-EBI GWAS Catalog of published genome-wide association studies, targeted arrays and summary statistics. Nucleic Acids Res. 2019, 47, D1005-D1012. [CrossRef] [PubMed]

93. Postema, P.; Wilde, A. The Measurement of the QT Interval. Curr. Cardiol. Rev. 2014, 10, 287-294. [CrossRef] [PubMed]

94. Aarnoudse, A.J.L.H.J.; Newton-Cheh, C.; De Bakker, P.I.W.; Straus, S.M.J.M.; Kors, J.A.; Hofman, A.; Uitterlinden, A.G.; Witteman, J.C.M.; Stricker, B.H.C. Common NOS1AP variants are associated with a prolonged QTc interval in the rotterdam study. Circulation 2007, 116, 10-16. [CrossRef] [PubMed]

95. Post, W.; Shen, H.; Damcott, C.; Arking, D.E.; Kao, W.H.L.; Sack, P.A.; Ryan, K.A.; Chakravarti, A.; Mitchell, B.D.; Shuldiner, A.R. Associations between genetic variants in the NOS1AP (CAPON) gene and cardiac repolarization in the Old Order Amish. Hum. Hered. 2007, 64, 214-219. [CrossRef] [PubMed]

96. Crotti, L.; Monti, M.C.; Insolia, R.; Peljto, A.; Goosen, A.; Brink, P.A.; Greenberg, D.A.; Schwartz, P.J.; George, A.L., Jr. NOS1AP is a genetic modifier of the long-QT syndrome. Circulation 2009, 120, 1657-1663. [CrossRef] [PubMed]

97. Tomás, M.; Napolitano, C.; De Giuli, L.; Bloise, R.; Subirana, I.; Malovini, A.; Bellazzi, R.; Arking, D.E.; Marban, E.; Chakravarti, A.; et al. Polymorphisms in the NOS1AP Gene Modulate QT Interval Duration and Risk of Arrhythmias in the Long QT Syndrome. J. Am. Coll. Cardiol. 2010, 55, 2745-2752. [CrossRef] [PubMed]

98. Gouas, L.; Nicaud, V.; Berthet, M.; Forhan, A.; Tiret, L.; Balkau, B.; Guicheney, P. Association of KCNQ1, KCNE1, KCNH2 and SCN5A polymorphisms with QTC interval length in a healthy population. Eur. J. Hum. Genet. 2005, 13, 1213-1222. [CrossRef] 
99. Pfeufer, A.; Van Noord, C.; Marciante, K.D.; Arking, D.E.; Larson, M.G.; Smith, A.V.; Tarasov, K.V.; Müller, M.; Sotoodehnia, N.; Sinner, M.F.; et al. Genome-wide association study of PR interval. Nat. Genet. 2010, 42, 153-159. [CrossRef]

100. Cheng, S.; Keyes, M.J.; Larson, M.G.; McCabe, E.L.; Newton-Cheh, C.; Levy, D.; Benjamin, E.J.; Vasan, R.S.; Wang, T.J. Long-term outcomes in individuals with prolonged PR interval or first-degree atrioventricular block. J. Am. Med. Assoc. 2009, 301, 2571-2577. [CrossRef]

101. Desai, A.D.; Yaw, T.S.; Yamazaki, T.; Kaykha, A.; Chun, S.; Froelicher, V.F. Prognostic Significance of Quantitative QRS Duration. Am. J. Med. 2006, 119, 600-606. [CrossRef]

102. Bezzina, C.R.; Shimizu, W.; Yang, P.; Koopmann, T.T.; Tanck, M.W.T.; Miyamoto, Y.; Kamakura, S.; Roden, D.M.; Wilde, A.A.M. Common sodium channel promoter haplotype in Asian subjects underlies variability in cardiac conduction. Circulation 2006, 113, 338-344. [CrossRef] [PubMed]

103. Hoffmann, S.; Clauss, S.; Berger, I.M.; Weiß, B.; Montalbano, A.; Röth, R.; Bucher, M.; Klier, I.; Wakili, R.; Seitz, H.; et al. Coding and non-coding variants in the SHOX2 gene in patients with early-onset atrial fibrillation. Basic Res. Cardiol. 2016, 111, 36. [CrossRef] [PubMed]

104. Vincentz, J.W.; Firulli, B.A.; Toolan, K.P.; Arking, D.E.; Sotoodehnia, N.; Wan, J.; Chen, P.S.; De Gier-De Vries, C.; Christoffels, V.M.; Rubart-Von Der Lohe, M.; et al. Variation in a Left Ventricle-Specific Hand1 Enhancer Impairs GATA Transcription Factor Binding and Disrupts Conduction System Development and Function. Circ. Res. 2020, 125, 575-589. [CrossRef] [PubMed]

105. Salman, O.F.; El-Rayess, H.M.; Abi Khalil, C.; Nemer, G.; Refaat, M.M. Inherited Cardiomyopathies and the Role of Mutations in Non-coding Regions of the Genome. Front. Cardiovasc. Med. 2018, 5, 77. [CrossRef] [PubMed]

106. He, J.; Luo, Y.; Song, J.; Tan, T.; Zhu, H. Non-coding RNAs and Pathological Cardiac Hypertrophy. Adv. Exp. Med. Biol. 2020, 1229, 231-245. [PubMed]

107. Han, P.; Li, W.; Lin, C.H.; Yang, J.; Shang, C.; Nurnberg, S.T.; Jin, K.K.; Xu, W.; Lin, C.Y.; Lin, C.J.; et al. A long noncoding RNA protects the heart from pathological hypertrophy. Nature 2014, 514, 102-106. [CrossRef] [PubMed]

108. Campuzano, O.; Sarquella-Brugada, G.; Cesar, S.; Arbelo, E.; Brugada, J.; Brugada, R. Update on Genetic Basis of Brugada Syndrome: Monogenic, Polygenic or Oligogenic? Int. J. Mol. Sci. 2020, 21, 7155. [CrossRef]

109. Brugada, J.; Campuzano, O.; Arbelo, E.; Sarquella-Brugada, G.; Brugada, R. Present Status of Brugada Syndrome: JACC State-of-the-Art Review. J. Am. Coll. Cardiol. 2018, 72, 1046-1059. [CrossRef]

110. Probst, V.; Hoorntje, T.M.; Hulsbeek, M.; Wilde, A.A.M.; Escande, D.; Mannens, M.M.A.M.; Le Marec, H. Cardiac conduction defects associate with mutations in SCN5A. Nat. Genet. 1999, 23, 20-21.

111. Watanabe, H.; Yang, T.; Stroud, D.M.; Lowe, J.S.; Harris, L.; Atack, T.C.; Wang, D.W.; Hipkens, S.B.; Leake, B.; Hall, L.; et al. Striking in vivo phenotype of a disease-associated human scn5a mutation producing minimal changes in vitro. Circulation 2011, 124, 1001-1011. [CrossRef]

112. Wilde, A.A.M.; Postema, P.G.; Di Diego, J.M.; Viskin, S.; Morita, H.; Fish, J.M.; Antzelevitch, C. The pathophysiological mechanism underlying Brugada syndrome. Depolarization versus repolarization. J. Mol. Cell. Cardiol. 2010, 49, 543-553. [CrossRef] [PubMed]

113. Burashnikov, E.; Pfeiffer, R.; Barajas-Martinez, H.; Delpón, E.; Hu, D.; Desai, M.; Borggrefe, M.; Hissaguerre, M.; Kanter, R.; Pollevick, G.D.; et al. Mutations in the cardiac L-type calcium channel associated with inherited J-wave syndromes and sudden cardiac death. Hear. Rhythm 2020, 7, 1872-1882. [CrossRef] [PubMed]

114. Wilde, A.A.M.; Amin, A.S. Clinical Spectrum of SCN5A Mutations: Long QT Syndrome, Brugada Syndrome, and Cardiomyopathy. JACC Clin. Electrophysiol. 2018, 4, 569-579. [CrossRef] [PubMed]

115. Walsh, R.; Wilde, A.A.M. SCN5A variants in Brugada syndrome: True, true false, or false true. J. Cardiovasc. Electrophysiol. 2019, 30, 128-131. [CrossRef] [PubMed]

116. Leoni, A.-L.; Gavillet, B.; Rougier, J.-S.; Marionneau, C.; Probst, V.; Le Scouarnec, S.; Schott, J.-J.; Demolombe, S.; Bruneval, P.; Huang, C.L.H.; et al. Variable Nav1.5 Protein Expression from the Wild-Type Allele Correlates with the Penetrance of Cardiac Conduction Disease in the Scn5a+/- Mouse Model. PLoS ONE 2010, 5, e9298. [CrossRef]

117. Tarradas, A.; Pinsach-Abuin, M.; Mackintosh, C.; Llorà-Batlle, O.; Pérez-Serra, A.; Batlle, M.; Pérez-Villa, F.; Zimmer, T.; Garcia-Bassets, I.; Brugada, R.; et al. Transcriptional regulation of the sodium channel gene (SCN5A) by GATA4 in human heart. J. Mol. Cell. Cardiol. 2017, 102, 74-82. [CrossRef] 
118. AlSayed, Z.R.; Canac, R.; Cimarosti, B.; Bonnard, C.; Gourraud, J.-B.; Hamamy, H.; Kayserili, H.; Girardeau, A.; Jouni, M.; Jacob, N.; et al. Human model of IRX5 mutations reveals key role for this transcription factor in ventricular conduction. Cardiovasc. Res. 2020, 259. [CrossRef]

119. Yang, P.; Koopmann, T.T.; Pfeufer, A.; Jalilzadeh, S.; Schulze-Bahr, E.; Kääb, S.; Wilde, A.A.; Roden, D.M.; Bezzina, C.R. Polymorphisms in the cardiac sodium channel promoter displaying variant in vitro expression activity. Eur. J. Hum. Genet. 2008, 16, 350-357. [CrossRef]

120. Park, J.K.; Martin, L.J.; Zhang, X.; Jegga, A.G.; Benson, D.W. Genetic variants in SCN5A promoter are associated with arrhythmia phenotype severity in patients with heterozygous loss-of-function mutation. Hear. Rhythm 2012, 9, 1090-1096. [CrossRef]

121. Yagihara, N.; Watanabe, H.; Barnett, P.; Duboscq-Bidot, L.; Thomas, A.C.; Yang, P.; Ohno, S.; Hasegawa, K.; Kuwano, R.; Chatel, S.; et al. Variants in the SCN5A Promoter Associated With Various Arrhythmia Phenotypes. J. Am. Heart Assoc. 2016, 5, 1-10. [CrossRef]

122. Matsumura, H.; Nakano, Y.; Ochi, H.; Onohara, Y.; Sairaku, A.; Tokuyama, T.; Tomomori, S.; Motoda, C.; Amioka, M.; Hironobe, N.; et al. H558R, a common SCN5A polymorphism, modifies the clinical phenotype of Brugada syndrome by modulating DNA methylation of SCN5A promoters. J. Biomed. Sci. 2017, 24, 1-10. [CrossRef] [PubMed]

123. Akopian, A.N.; Sivilotti, L.; Wood, J.N. A tetrodotoxi n-resistant voltage-gated sodium channel expressed by sensory neurons. Nature 1996, 379, 257-262. [CrossRef] [PubMed]

124. Benn, S.C.; Costigan, M.; Tate, S.; Fitzgerald, M.; Woolf, C.J. Developmental expression of the TTX-resistant voltage-gated sodium channels Nav1.8 (SNS) and Nav1.9 (SNS2) in primary sensory neurons. J. Neurosci. 2001, 21, 6077-6085. [CrossRef] [PubMed]

125. Fukuoka, T.; Noguchi, K. Comparative study of voltage-gated sodium channel $\alpha$-subunits in non-overlapping four neuronal populations in the rat dorsal root ganglion. Neurosci. Res. 2011, 70, 164-171. [CrossRef] [PubMed]

126. Verkerk, A.O.; Remme, C.A.; Schumacher, C.A.; Scicluna, B.P.; Wolswinkel, R.; De Jonge, B.; Bezzina, C.R.; Veldkamp, M.W. Functional NaV1.8 channels in intracardiac neurons: The link between SCN10A and cardiac electrophysiology. Circ. Res. 2012, 111, 333-343. [CrossRef] [PubMed]

127. Stroud, D.M.; Yang, T.; Bersell, K.; Kryshtal, D.O.; Nagao, S.; Shaffer, C.; Short, L.; Hall, L.; Atack, T.C.; Zhang, W.; et al. Contrasting Nav1.8 activity in Scn10a-/- ventricular myocytes and the intact heart. J. Am. Heart Assoc. 2016, 5. [CrossRef] [PubMed]

128. Yang, T.; Atack, T.C.; Stroud, D.M.; Zhang, W.; Hall, L.; Roden, D.M. Blocking Scn10a channels in heart reduces late sodium current and is antiarrhythmic. Circ. Res. 2012, 111, 322-332. [CrossRef]

129. Dybkova, N.; Ahmad, S.; Pabel, S.; Tirilomis, P.; Hartmann, N.; Fischer, T.H.; Bengel, P.; Tirilomis, T.; Ljubojevic, S.; Renner, A.; et al. Differential regulation of sodium channels as a novel proarrhythmic mechanism in the human failing heart. Cardiovasc. Res. 2018, 114, 1728-1737. [CrossRef]

130. Casini, S.; Marchal, G.A.; Kawasaki, M.; Nariswari, F.A.; Portero, V.; van den Berg, N.W.E.; Guan, K.; Driessen, A.H.G.; Veldkamp, M.W.; Mengarelli, I.; et al. Absence of Functional Nav1.8 Channels in Non-diseased Atrial and Ventricular Cardiomyocytes. Cardiovasc. Drugs Ther. 2019, 33, 649-660. [CrossRef]

131. Veerman, C.C.; Podliesna, S.; Tadros, R.; Lodder, E.M.; Mengarelli, I.; De Jonge, B.; Beekman, L.; Barc, J.; Wilders, R.; Wilde, A.A.M.; et al. The brugada syndrome susceptibility gene HEY2 modulates cardiac transmural ion channel patterning and electrical heterogeneity. Circ. Res. 2017, 121, 537-548. [CrossRef]

132. Van Den Boogaard, M.; Smemo, S.; Burnicka-Turek, O.; Arnolds, D.E.; Van De Werken, H.J.G.; Klous, P.; McKean, D.; Muehlschlegel, J.D.; Moosmann, J.; Toka, O.; et al. A common genetic variant within SCN10A modulates cardiac SCN5A expression. J. Clin. Investig. 2014, 124, 1844-1852. [CrossRef] [PubMed]

133. Van Den Boogaard, M.; Barnett, P.; Vincent, M.; Van Den Boogaard, M.; Wong, L.Y.E.; Tessadori, F.; Bakker, M.L. Genetic variation in T-box binding element functionally affects SCN5A/SCN10A enhancer Find the latest version: Genetic variation in T-box binding element functionally affects SCN5A/SCN10A enhancer. J. Clin. Investig. 2012, 122, 2519-2530. [CrossRef] [PubMed]

134. Arnolds, D.E.; Liu, F.; Fahrenbach, J.P.; Kim, G.H.; Schillinger, K.J.; Smemo, S.; McNally, E.M.; Nobrega, M.A.; Patel, V.V.; Moskowitz, I.P. TBX5 drives Scn5a expression to regulate cardiac conduction system function. J. Clin. Investig. 2012, 122, 2509-2518. [CrossRef] [PubMed]

135. Man, J.C.K.; Mohan, R.A.; van den Boogaard, M.; Hilvering, C.R.E.; Jenkins, C.; Wakker, V.; Bianchi, V.; de Laat, W.; Barnett, P.; Boukens, B.J.; et al. An enhancer cluster controls gene activity and topology of the SCN5A-SCN10A locus in vivo. Nat. Commun. 2019, 10, 1-15. [CrossRef] [PubMed] 
136. London, B. Whither Art Thou, SCN10A, and What Art Thou Doing? Circ. Res. 2012, 111, 268-270. [CrossRef]

137. Yang, B.; Lin, H.; Xiao, J.; Lu, Y.; Luo, X.; Li, B.; Zhang, Y.; Xu, C.; Bai, Y.; Wang, H.; et al. The muscle-specific microRNA miR-1 regulates cardiac arrhythmogenic potential by targeting GJA1 and KCNJ2. Nat. Med. 2007, 13, 486-491. [CrossRef]

138. Wahlquist, C.; Jeong, D.; Rojas-Muñoz, A.; Kho, C.; Lee, A.; Mitsuyama, S.; Van Mil, A.; Jin Park, W.; Sluijter, J.P.G.; Doevendans, P.A.F.; et al. Inhibition of miR-25 improves cardiac contractility in the failing heart. Nature 2014, 508, 531-535. [CrossRef]

139. Luo, X.; Pan, Z.; Shan, H.; Xiao, J.; Sun, X.; Wang, N.; Lin, H.; Xiao, L.; Maguy, A.; Qi, X.Y.; et al. MicroRNA-26 governs profibrillatory inward-rectifier potassium current changes in atrial fibrillation. J. Clin. Investig. 2013, 123, 1939-1951. [CrossRef]

140. Van Rooij, E.; Sutherland, L.B.; Thatcher, J.E.; DiMaio, J.M.; Naseem, R.H.; Marshall, W.S.; Hill, J.A.; Olson, E.N. Dysregulation of microRNAs after myocardial infarction reveals a role of miR-29 in cardiac fibrosis. Proc. Natl. Acad. Sci. USA 2008, 105, 13027-13032. [CrossRef]

141. Lu, Y.; Zhang, Y.; Wang, N.; Pan, Z.; Gao, X.; Zhang, F.; Zhang, Y.; Shan, H.; Luo, X.; Bai, Y.; et al. MicroRNA-328 contributes to adverse electrical remodeling in atrial fibrillation. Circulation 2010, 122, 2378-2387. [CrossRef]

142. Daimi, H.; Lozano-Velasco, E.; Haj Khelil, A.; Chibani, J.B.E.; Barana, A.; Amorós, I.; González De La Fuente, M.; Caballero, R.; Aranega, A.; Franco, D. Regulation of SCN5A by microRNAs: MiR-219 modulates SCN5A transcript expression and the effects of flecainide intoxication in mice. Heart Rhythm 2015, 12, 1333-1342. [CrossRef] [PubMed]

143. Zhou, R.; Hang, P.; Zhu, W.; Su, Z.; Liang, H.; Du, Z. Whole Genome Network Analysis of Ion Channels and Connexins in Myocardial Infarction. Cell. Physiol. Biochem. 2011, 27, 299-304. [CrossRef] [PubMed]

144. Zhang, X.; Yoon, J.Y.; Morley, M.; McLendon, J.M.; Mapuskar, K.A.; Gutmann, R.; Mehdi, H.; Bloom, H.L.; Dudley, S.C.; Ellinor, P.T.; et al. A common variant alters SCN5A-miR-24 interaction and associates with heart failure mortality. J. Clin. Investig. 2018, 128, 1154-1163. [CrossRef] [PubMed]

145. Song, X.; You, W.; Zhu, J.; Cui, X.; Hu, J.; Chen, Y.; Liu, W.; Wang, L.; Li, S.; Wei, Y.; et al. A Genetic Variant in miRNA-219-1 Is Associated with Risk of Esophageal Squamous Cell Carcinoma in Chinese Kazakhs. Dis. Markers 2015, 2015, 541531. [CrossRef] [PubMed]

146. Daimi, H.; Franco, D. Regulation of SCN5A by Non-coding RNAs in the Brugada Syndrome Context. J. Cardiol. Cardiovasc. Sci. 2020, 4, 65-70. [CrossRef]

147. Franco, D.; Aranega, A.; Dominguez, J.N. Non-coding RNAs and Atrial Fibrillation. Adv. Exp. Med. Biol. 2020, 1229, 311-325. [CrossRef]

148. Shen, C.; Kong, B.; Liu, Y.; Xiong, L.; Shuai, W.; Wang, G.; Quan, D.; Huang, H. YY1-induced upregulation of lncRNA KCNQ1OT1 regulates angiotensin II-induced atrial fibrillation by modulating miR-384b/CACNA1C axis. Biochem. Biophys. Res. Commun. 2018, 505, 134-140. [CrossRef]

149. Mei, B.; Liu, H.; Yang, S.; Liang, M.Y.; Yue, Y.; Huang, S.Q.; Hou, J.; Chen, G.X.; Wu, Z.K. Long non-coding RNA expression profile in permanent atrial fibrillation patients with rheumatic heart disease. Eur. Rev. Med. Pharmacol. Sci. 2018, 22, 6940-6947. [CrossRef]

150. Ruan, Z.; Sun, X.; Sheng, H.; Zhu, L. Long non-coding RNA expression profile in atrial fibrillation. Int. J. Clin. Exp. Pathol. 2015, 8, 8402-8410.

151. Sendfeld, F.; Selga, E.; Scornik, F.S.; Pérez, G.J.; Mills, N.L.; Brugada, R. Experimental models of brugada syndrome. Int. J. Mol. Sci. 2019, 20, 2123. [CrossRef]

Publisher's Note: MDPI stays neutral with regard to jurisdictional claims in published maps and institutional affiliations.

(C) 2020 by the authors. Licensee MDPI, Basel, Switzerland. This article is an open access article distributed under the terms and conditions of the Creative Commons Attribution (CC BY) license (http://creativecommons.org/licenses/by/4.0/). 